\title{
ČLÁNKY
}

\section{V jakém smyslu je řecká tragédie politická? ${ }^{i}$}

\author{
Jaroslav Daneš
}

Odpověd' na otázku vznesenou v názvu článku se rozpadá do dvou bodů. Za prvé je možné zkoumat divadlo jako státem organizovanou a dozorovanou instituci v rámci svátku Velkých Dionýsií, kdy se soutěž tragiků konala; za druhé analyzovat obsah samotných her ve vztahu k polis a občanskému diskurzu či ,ideologii“ Athén.

\section{Divadlo jako politická instituce}

To, že svátky byly, jsou a pravděpodobně i nadále budou využívány také k politickým účelů, je všeobecně známá skutečnost. Nejinak tomu bylo i ve starověkém Řecku. Např́klad Hérodotos (V. 67) zmiňuje zákaz soutěže v recitaci Homéra tyranem Kleisthénem v Sikyónu, protože pěvci opěvovali Argos a Argejce, kteř́ byli jeho úhlavními nepřáteli. Ve stejné pasáži dále popisuje Kleisthénovo tažení proti kultu héroa Adrásta a jeho nahrazení kultem Adrástova nepř́itele héroa Melanippa. Všechny oběti a svátky, které se konaly v rámci Adrástova kultu, se nadále měly odehrávat na počest Melanippovu, čímž dosáhl ideologické proměny za doby své vlády.

\footnotetext{
i Tento článek je upravenou verzí přednášky téhož názvu, která byla přednesena 4.2. 2010 v Odděleni pro nejstarši evropskou a českou filosofii FLU AV ČR. Článek vznikl v rámci projektu GAČR 401/09/P032 Řecká tragická poezie a politické myšlení.
} 
Počátky spojení athénských tragických představení se svátkem Velkých Dionýsií jsou nejasné. Nevíme, kdy byl zaveden svátek Velkých Dionýsií, i když bychom mohli předpokládat, že se tak stalo za Peisistrata, který uvedl Dionýsův kult do Athén, aby ideově podpořil svou vládu. Pokud jde o tragická představení, oba zdroje, které máme k dispozici, datují jejich počátky spojené s Thespidovým jménem do doby vlády tyrana Peisistrata. ${ }^{i}$ Nejsou však považovány za nezvratné. Přes sporé doklady a nejasné počátky se moderní interpreti shodují v jedné věci, že tragická představení a nový svátek měly významný politický aspekt. Connor hájil tezi, že Velké Dionýsie a tragická představení měla být oslavou osvobození Athén od tyranů a systému vzešlého z Kleisthénových reforem, neboli že dramatické soutěže jsou úzce spojeny s demokracií. ${ }^{i i}$ Naproti tomu Csapo a Slater zastávali názor, že nový svátek měl stmelit athénské občany, ukázat moc sjednoceného státu a přispět ke kulturní identitě Athéňanů. Jinými slovy, svátek byl př́ležitostí k oslavě státu a snad i Peisistrata samotného. iii Osborne poznamenává, že skutečnost, zda nový svátek a představení využívali Peisitratovci, nebo nový demokratický systém, nehraje prŕíliš velkou roli, nebot' představení a svátky byly potřebou polis a způsobem, jak podpořit a současně usměrnit soutěživost občanů. ${ }^{\text {iv }}$

Lepší přehled než o počátcích máme o tragických soutěžích v 5. století, z něhož také pocházejí všechny dochované tragédie, i když i zde naprostá většina informací pochází až od autorů 4. století a není jasné, zda to, co popisují, skutečně fungovalo i po celé 5. století. Velké či městské Dionýsie, během nichž se tragické soutěže konaly, byly nejvýznamnější athénskou slavností v průběhu roku, jíž se účastnil i značný počet cizinců. Organizace

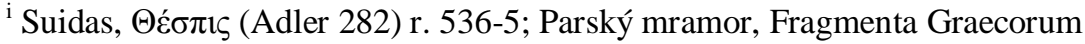
Historicorum, 239 A 43 (r. 542-520).

${ }^{\text {ii }}$ W. R. Connor, City Dionysia and Athenian Democracy in: Classica et Medievalia 40/1989, str. 7-32.

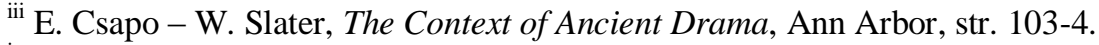

${ }^{\text {iv }} \mathrm{R}$. Osborne, Competitive festivals and the polis: a context for dramatic festivals at Athens, in: A. H. Sommerstein a kol., Tragedy, Comedy and the Polis, Bari 1993, str. 21-38.
} 
představení byla v rukou státu a jeho úředníků. Stát do určité míry dohlížel i na obsahovou náplň her. Autoři se totiž museli podrobit předběžnému výběru u archónta eponyma, v jehož pravomoci bylo rozhodnutí o přidělení sboru. Ten zkoumal obsahovou náplň sborových zpěvů. ${ }^{i} \mathrm{Z}$ dochovaných her je ale zřejmé, že se nejednalo o hrubou cenzuru, jak ji známe z moderních autoritativních a totalitních režimů. $\mathrm{Na}$ financování divadelních představení se podíleli i bohatí občané a předáci demokratické obce. Tato instituce se nazývala choregia a byla považována za prestižní. $\mathrm{Na}$ druhou stranu části aristokratů byla patrně trnem v oku, protože v pseudo-Xenofóntově Ústavě Athéňanů je popisována jako důkaz toho, jak lid sleduje své zájmy, nebot' nechá bohaté platit a sám z toho těží. ${ }^{i i}$ Víme, že mezi tragiky a „politiky“, kteří byli chorégy či archonty, byly úzké vazby a tyto osobnosti se mohly prostřednictvím divadla pokusit ovlivňovat názory lidu na aktuální politické otázky. ${ }^{\text {iii }}$ Zpočátku byl vstup

i Platón, Zákony 817d.

ii I. 13. Názory na to, zda se jedná o vysloveně demokratickou instituci, se různí. Wilson (The Athenian Institution of the Khoregia, Cambridge 2000, str. 144-197) zastává názor, že jde o demokratickou instituci, přesněji řečeno tvrdí, že „,neexistuje nic takového, jako je ideologicky neutrální uživání bohatství“(str. 172). Zmínky o chorégiích jako položkách na seznamu leiturgií ve sněmovních a soudních řečech athénských řečníků pomáhaly vytvářet obraz řečníka jako osoby, která je př́znivě nakloněna lidu a demokracii. Naopak to, že nějaký bohatý občan tyto povinnosti zanedbával, bylo známkou špatného vztahu k lidu a demokracii. Typickým prŕkladem je Démosthénova řeč Proti Meidiovi. Rhodes (Nothing to Do with Democracy in: Journal of Hellenic Studies 123/2003, str. 108) udává neméně dobré argumenty pro to, že se nejedná o výsostně demokratickou instituci. Rhodesovu argumentaci je možné shrnout následovně: 1 . i Wilson připouští, že jsou určité zmínky o tom, že instituce chorégie existovala i za Peisistratovců a dále v jiných řeckých obcích, které nebyly demokratické (Sparta, Aigina, Epidauros, Rhégion), 2. chorégie byla nástrojem, jak usměrnit aristokratickou soutěživost. iii Např́klad Thémistoklés, který byl zastáncem protiperské politiky a autorem programu výstavby válečného lod'stva (Thúkydidés I. 14), byl v roce 492 archóntem a odsouhlasil sbor Frýnichově hře Dobytí Mílétu, která reagovala na nedávnou tragickou porážku iónského povstání proti Peršanům. Thémistoklés se domníval, že tak získá nadšenější podporu pro své politické záměry, v Athéňanech 
na představení zdarma, ale boj o sedadla mezi občany a mezi občany a cizinci byl často tak vyhrocený, že vedl k zavedení vstupného. Chudí občané si však stěžovali, že boháči skupují sedadla, a proto byl zrrízen divácký fond ( $\theta \varepsilon \omega \rho$ ıкóv), ze kterého se přispívalo na vstupné. Opět ale nevíme, kdy se tak stalo. Tradice přisuzovala zrrízení tohoto fondu Perikleovi. ${ }^{\mathrm{i}} \mathrm{V}$ pseudo-Aristotelově Athénské ústavě (28) je ale zavedení př́spěvku na vstupné spojováno se jménem demagoga Kleofónta. Divácký fond hypertrofoval ve 4. století, kdy pohlcoval značnou část obecních financí a byly z něj poskytovány příspěvky na všechny athénské svátky. Není proto divu, že Démosthenés, který hledal finanční rezervy na armádní výdaje, usiloval o využití prostředků diváckého fondu na obranu proti Filipu Makedonskému. ${ }^{i i}$ Protože tragédiemi se soutěžilo, musela být vybrána nějaká porota k posouzení jednotlivých her. Porota měla pravděpodobně pět členů, avšak toto číslo je vzato ze zpráv o počtu členů poroty komických představení, nebot' $\mathrm{v}$ případě tragédie chybí doklady. ${ }^{i i i}$ Tito členové byli losováni z navržených kandidátů z deseti uren, které byly označeny prytany, zapečetěny chorégy a hlídány pokladníky na Akropoli. ${ }^{\text {iv }}$ V den zahájení představení byly přineseny do divadla, načež proběhlo losování a př́ísahy soudců, že budou soudit poctivě a nestranně. Známe však přinejmenším jeden př́ípad, kdy řevnivost publika byla tak velká, že bylo nutno přijmout mimořádná opatření. Proto byl za archónta Apsefióna

však Frýnichova hra vyvolala takový smutek a rozhořčení, že jej potrestali pokutou 1000 drachem (Hérodotos VI. 21).

${ }^{\text {i }}$ Plútarchos, Život Perikleưv 9. Plútarchos spojoval zavedení vstupného do divadla a platu za zasedání na soudě s Perikleovým bojem proti Kimónovu vlivu. Kimón disponoval velkým bohatstvím, které využíval k různým dobročinným skutkům, jimiž si získával u lidu populatiru. Periklés však takové bohatství neměl, a proto zvolil cestu rozdělování obecních peněz.

ii Démosthenés, Olynthská řeč I. 19, III. 19.

iii A. W. Pickard-Cambridge, The Attic Theater, New York 1969, str. 31.

iv Ísokratés XVII. 33-34. 
(r. 468) losovací mechanismus odstaven a na Apsefiónův prríkaz zasedlo jako porota deset stratégů neboli nejvyšších představitelů státu. ${ }^{\mathrm{i}}$

V nedávné době byla pod vlivem francouzské historiografie ${ }^{\mathrm{ii}}$ upřena pozornost i na ceremoniály, které předcházely uvedení tragédií, nebot' i v nich se odráží ideologie a moc athénského státu. Simon Goldhilliii připomíná přinejmenším čtyři ceremoniály s významnou politickou symbolikou:

1. Když si Isokratés stěžuje, jak hanebně nakládají Athéňané se spojenci a že jsou v tomto nepoučitelní, zmiňuje jako důkaz tohoto ostudného počínání rozhodnutí, podle něhož má být příspěvek obcí délského spolku neboli obcí pod ochranou či nadvládou athénského impéria - přinesen o Velkých Dionýsiích do divadla a vystaven. ${ }^{\text {iv }}$ Mrzkost tohoto počínání je dávána do kontrastu se vznešeností jednání Athén, jež byly za časů Miltiada a Aristeida lepší než v době demagogů Kleofóna a Hyperbola.

2. Současně byli na scénu přivedeni sirotci ve vojenské výstroji, jejichž otcové položili život $\mathrm{v}$ boji za vlast, načež bylo zdůrazněno, že byli vychováni a vyzbrojeni na státní útraty, a tito efébové následně složili

${ }^{\text {i }}$ Plútarchos, Život Kimónův 8.7-9.

${ }^{\text {ii }}$ Dobrý přehled lze získat z následujících prací N. Loraux, L'Invention d'Athènes: Histoire de l'oraison funèbre dans la cité classique, Paris 1981 a z výboru N. Loraux - G. Nagy - L .Slatkin, Antiquities: Postwar French Thought, New York 2001.

iii S. Goldhill, The Great Dionysia and Civic Ideology in: Journal of Hellenic Studies 107/1987, str. 58-76 přetištěno s opravami The Great Dionysia and Civic Ideology in: J. J. Winkler - F. I. Zeitlin, Nothing to Do with Dionysus? Princeton 1992, str. 100-107; Ve zkrácené verzi ve formě úvodu najdeme tyto Goldhillovy názory v Greek Drama and Political Theory in: Ch. Rowe - M. Schofield, The Cambridge History of Greek and Roman Political Thought. Cambridge 2000, str. 63.

iv Isokratés, O míru 82. Srov. Aristofanés, Acharňané 505 a 641-651. Tento ceremoniál nemohl být zaveden dř́ve než roku 453 a nemohl trvat déle než do roku 404, kdy délský spolek zanikl v důsledku porážky Athén v peloponnéské válce. 
př́sahu. Ísokratés tyto dva ceremoniály interpertuje tak, že Athéňané chtěli jednak před spojenci a ostatními Řeky demonstrovat své bohatství, jednak ukázat cenu, jakou je třeba zaplatit za úspěch imperiální politiky. I přes Ísokratovo kritické hodnocení athénské politiky nelze přehlédnout, že tyto ceremoniály byly svázány s athénskou sebeprezentací, což lze vyčíst i od jiných autorů.

3. O třetím ceremoniálu víme na základě soudního sporu o Démosthenovu korunovaci $\mathrm{v}$ divadle před athénských lidem, kterou navrhl Ktésifón a proti níž velmi ostře vystoupil Aischinés. ${ }^{i i}$ Před zaplněným hledištěm měla být vyhlášena jména těch, kdo se nějakým významným způsobem zasloužili o obec. Démosthenés vykládá ceremoniál v tom smyslu, že vůbec nejde o toho, kdo je věnčen, důležité je, že občané jsou touto událostí povzbuzeni vykonat něco pro stát, což je také důvod, proč stát zavedl tento ceremoniál zákonem. Aischinés nepopírá, že se před tragickými představeními něco takového dělo, ale rozvíjí podrobnou právní argumentaci, proč už se tak neděje a proč obec vydala nové zákony upravující takové pocty. Před představeními probíhalo totiž mnoho takových oznámení, vyhlášení a věnčení. Některé občany věnčily fýly, jiné démy, dále někteří občané nechali heroldy vyhlásit, že propouštějí na svobodu otroky a činí tak před zraky všech občanů a Řeků, kromě těchto skupin se našli i občané, kteří podle Aischina patřili mezi nejzávistivější a nechali vyhlásit, že jako proxenové získali pocty a věnce od lidu jiných obcí, napřr. Rhodu a Chiu. Proto byl vydán zákon, který umožňoval dosíci takových poct pouze v radě a na sněmu, nebot' tam mají mandát lidu, zatímco ceremoniál na divadle se týkal osob, které chtěli vyhlásit a odměnit cizinci. I ti si však museli před tím vyžádat souhlas sněmu. Nevíme však nic o chronologii těchto zákonů a ceremoniálů z literatury a mlčí dokonce i nápisy. ${ }^{\text {iii }}$

\footnotetext{
${ }^{\mathrm{i}}$ Aristofanés, Acharňané 496-510.

${ }^{i i}$ Démosthenés, O věnci 120; Aischinés, Proti Ktésifóntovi 46-51.

${ }^{i i i}$ Viz P. J. Rhodes, Nothing to Do with Democracy: Athenian Drama and the Polis, in: Journal of Hellenic Studies 123/2003, str. 112.
} 
4. Posledním diskutovaným ceremoniálem jsou úlitby bohům, které měli provádět stratégové před začátkem představení. Zde se Goldhill opírá o již zmiňovanou pasáž z Plútarchova Života Kimónova, kde se říká, že Kimón „po př́chodu do divadla se svými spoluveliteli vykonal předepsané úlitby“. 'Tato Plútarchova informace o ze symbolického hlediska významném politickém aktu je potvrzena nápisem ze 4 . stoletíii , kde se hovoří jednak o tom, že stratégové vykonávali náboženské úkony během dramatických představení, a také o tom, že všech deset stratégů pohromadě bylo $\mathrm{v}$ průběhu roku $\mathrm{k}$ vidění jen zřídka a vždy při výjimečných

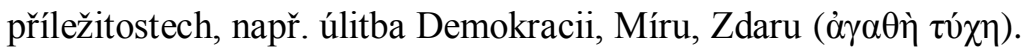

Tyto ceremoniály můžeme srovnat $\mathrm{s}$ jinou athénskou institucí, a to $\mathrm{s}$ pohřební řečí. Vezmeme-li však jako příklad Perikleovu řeč u Thúkydida, kde jsou jasně zachyceny demokratické hodnoty a ideály, nemají uvedené ceremoniály předcházející tragickým představením demokratický akcent, jak si myslí Goldhill, ale spíše akcent velmocenský a reprezentativní: ekonomická moc a vojenská síla. Demokratický podtext má pouze třetí ceremoniál, což je patrné především z Aischinovy řeči. Jak už ale bylo řečeno, nevíme nic o tom, kdy byl zaveden, kdy doznal změn a kdy došlo k právním úpravám, o nichž Aischinés mluví. Divadlo tedy bylo institucí ve státním soukolí s významnou reprezentativní a ideologickou funkcí, čemuž se budeme věnovat i ve druhé části tohoto článku.

\section{Politický obsah tragédií}

Dříve, než se budu zabývat dvěma konkrétními motivy, je třeba pokusit se definovat politično. Pokud vyjdeme z Aristotelovy charakteristiky člověka

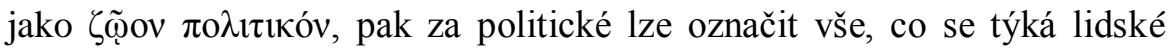
bytosti jako části společenství. To je velmi široká definice, která pokrývá

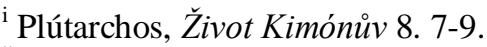

ii IG II 1496.
} 
natolik různé oblasti, jakými jsou občanská výchova, výkon moci, procedury rozhodování, hodnoty zastávané určitým společenstvím, ideologie, sebeprezentace a sebepochopení, identita a odlišnost, občanství a exkluze atd. Proto je možné říci, že různé tragédie jsou politické různým způsobem. ${ }^{i} \mathrm{~S}$ ohledem na závěr předcházející části se však zaměřím na to, jak jsou vjednotlivých hrách prezentovány Athény. Pokud totiž stát využíval svátku Velkých Dionýsií k sebeprezentaci, demonstraci i oslavě své velkoleposti a síly a financoval ve spolupráci s bohatými občany divadelní soutěže, pak lze očekávat, že i v hrách samých bude tento aspekt nějak patrný.

Osm různých tragédií oslavuje Athény jako útočiště prosebníků.i Motiv azylu je silný a rozpoznatelný nejen v tragédii, ale též u athénských řečníků konce 5. a první poloviny 4. století. ${ }^{\text {iii }}$ Tento rys Athén je však i parodován v tom smyslu, že Athény jsou přesprŕiliš lítostivé a dají vždy přednost slabším před silnými přáteli, přričemž slabým až jakoby přisluhují. ${ }^{\text {iv }}$ Vezmu jako typický prŕíklad dvě Eurípidovy hry, z nichž ta druhá spojuje právě tragédii a řečnictví, přesněji řečeno, attičtí řečníci právě tento mythos, jež zpracoval Eurípidés, velmi často využívají: Hérakleovci a Prosebnice.

VHérakleovcích hledají útočiště v Athénách Hérakleovy děti pronásledované mykénským králem Eurystheem. Moci a vlivu Eurystheovu se žádná země nechce vzpírat, a proto není nikdo ochoten poskytnout azyl Hérakleově rodině, jak vyplývá z řeči Eurystheova posla

\footnotetext{
i Detailní rozbor této otázky podává D. M. Carter, The Politics of Greek Tragedy, Bristol 2007, str. 21-142.

ii Aischylos, Eumenidy; Sofoklés, Oidipús na Kolónu; Eurípidés, Prosebnice, Héraklés, Hérakleovci, Medea, Élektra a Orestés (u posledních dvou jako předpověd' budoucnosti).

iii Lysias, Pohřební řeč 7-11; Ísokratés, Panathenaikos 168-174, Panegyrikos 5458, Démosthenés 60.8 Srov. Lykúrgos, Proti Leokratovi 98, Xenofón, Hellénika VI. 5. 46.

${ }^{\text {iv }}$ Platón, Menexenos 244e; Andokidés, $O$ míru 28; Démosthenés, Proti Leptinovi 3.
} 
Koprea (55-60). Kopreus je prripraven znesvětit i oltáře a porušit všechna nepsaná pravidla, aby odvlekl Hérakleovy děti. Jak sbor, tak athénský král Démofón, který přispěchal na místo, když slyšel o prosebnících, dávají Kopreovi jednoznačně najevo, že se nechová jako Řek, ale jako barbar (130-1), a nadto uráží jejich důstojnost a čest, nebot' si počíná, jako by byl v porobené zemi, přestože se nachází v zemi svobodné (111-13). Když se svévolnému jednání Kopreovu postaví Athéňané na odpor, začíná něco, co připomíná soudní debatu, kdy obě strany mají přednést svou verzi případu. Kopreus trvá na vydání Hérakleovců, protože byli odsouzeni podle argejského zákona (141-2). Druhou část jeho řeči tvoří diplomacie. Nejprve nabídne spojenectví s mocným státem (155-7) a vzápětí dává Athéňanům ultimátum: bud'to nám uprchlíky vydáte, nebo bude válka (158-160). Ioláos se hájí tím, že Hérakleovci nemají s Argem nic společného, naopak byli z této země vyhnáni a teprve později tamtéž odsouzeni (184-8). Jeho výklad plynule přechází v oslavu Athén. Athény jsou obcí svobodnou, hrdou a odvážnou (191-202). Důvodem, proč by Démofón neměl Hérakleovce vyhnat ze země a poskytnut jim útočiště, je pokrevní př́ibuznost, protože Pittheus, syn Pelopův, byl otcem Aithry, Theseovy matky, a Alkméné, matka Hérakleova, byla vnučkou Pelopovou (205-12). Kromě pokrevního př́buzenství zmiňuje Ioláos ještě dávný závazek. Héraklés totiž zachránil Démofóntovu otci Theseovi život a vyvedl jej z Hádu (215-19). Démofón nakonec azyl prosebníkům poskytne, a to na základě tří důvodů: zbožnost, příbuzenství, hrdost (236-50). Démofón $\mathrm{k}$ třetímu důvodu $\mathrm{v}$ podstatě říká následující: v naší svobodné zemi má přednost zbožné a čestné jednání, nikdo nám nebude nic nařizovat a nikdo nám nebude vyhrožovat. Pokud tak někdo učiní, jsme připraveni se bránit $\mathrm{i}$ za cenu války a proti velmi silnému nepř́iteli (284-9). Ioláa vede Démofontovo rozhodnutí $\mathrm{k}$ další oslavě Athén a krále. ${ }^{\mathrm{i}}$

\footnotetext{
i Téma Hérakleovců jako prosebníků má také konkrétní historický kontext, kterým je počínající peloponnéská válka. V Ioláově řeči k Hérakleovým dětem po Démofontově rozhodnutí se nachází následují pasáž:
} 
V Eurípidových Prosebnicích přicházejí matky padlých argejských hrdinů spolu s králem Adrástem do Athén požádat o pomoc při vydání těl svých synů, aby je mohly pohřbít, nebot' thébský král Kreón je hrubě odmítl. Athénský král Théseus se nejprve zdráhá, protože Argejci neuposlechli špatných věštných znamení, která je od válečného tažení odrazovala. Adrástovi vyčíá, že se nechal svést na zcestí mladými muži, kteří prahnou po poctách $\mathrm{v}$ boji, a proto nedbají nijak na spravedlnost a vyvolávají války (224-34). Nakonec je ale přemluvem svou matkou Aithrou (297-331) a ujímá se nesnadného úkolu získat těla mrtvých reků. Théseus okamžitě udílí pokyny svému poslu, který má předat dva vzkazy. Prvním je žádost, aby Thébané vydali těla dobrovolně, a tak utužili sousedské vztahy a současně učinili zadost náboženským povinnostem. Kdyby ale Thébané odmítli Théseovu žádost, vytáhne proti nim athénská armáda (385-94).

„Vrátíte-li se jednou do své země zpět a otcovskou čest zas získáte a rodný dům, ctěte $\mathrm{v}$ nich zachránce a věrné přátele a toho pamětlivi nezdvihněte zbraň zde proti této zemi. Pro vás Athény at' navždy jsou státem ze všech nejdražším. “ (310-16; Eurípidés: Héraklés a jiné tragédie. Praha 1988, str. 230)

Tato pasáž je výtkou Spart’anům, kteří byli potomky Hérakleovců, že kdysi Athéňané s nasazením vlastních životů poskytli útočiště jejich předkům a Spart'ané nyní proti Athénám vedou válku, čímž dokazují svou nevděčnost. Tento motiv zaznívá ještě jednou v závěru hry, kdy se rozhoduje o smrti mykénského krále Eurysthea:

Eurystheus: „Zabij mě, o milost neprosím. Městu však, jež ušetřilo mě, mé smrti štítí se, chci zjevit starou věštbu Apollónovu. Bude mu platna víc, než snad se může zdát. Až zemřu, pohřběte mě, kde je určeno, před chrámem bohyně Pallénské Athény. Ve vaší zemi budu ležet, pro vás príitel a věrný ochránce pro obec athénskou, však pro potomky Hérakleovců nepř́itel, až přitáhnou sem $\mathrm{s}$ velkou mocí vojenskou, zapomenuvše na vděk. Ano, takové př́tele chráníte.“(1026-37; Eurípidés: Héraklés a jiné tragédie. Praha 1988, str. 259). Ačkoli v každé hře je mnoho rovin, jedna $\mathrm{z}$ nich je zde naprosto zřetelná a velmi výstižně popsána Králem v jejím hodnocení: „Je to parainetická (dnes bychom řekli agitační) vlastenecká činohra, tendenčně oslavující básníkovu vlast, Athény, jako odvěkého zastánce práva a spravedlnosti a ochránce všech slabých, utiskovaných, ukřivděných a nespravedlivě stíhaných. Osten je namíren proti historickému nevděku Spartanů." (Eurípidés: Héraklés a jiné tragédie. Praha 1988, str. 214.) 
Athény jsou tedy nejen útočištěm prosebníků, ale současně i ochráncem spravedlnosti, práva a zbožnosti, nebot' pohřbít mrtvé je zákon, jenž platí pro všechny Řeky (525-7; 671-2) a je to zákon božský a starobylý (563). Théseus nakonec musí užít vojenské síly a jeho mise dopadne úspěšně. Závěr Prosebnic obsahuje připomenutí závazku, které mají Argejci vůči Athénám. Jde o pasáž podobnou Ioláově instruktáži Hérakleových potomků v Hérakleovcích. Plyne z ní, že Athény je třeba mít v úctě, nebot' už pro prosebníky podstoupily nemálo námahy a útrap, a vždy si být vědom toho závazku a nikdy proti Athénám neobracet zbraně. ${ }^{i}$

Druhým významným momentem, jenž souvisí se sebeprezentací Athén, je charakteristika Athén jako vůdce Řecka a velmoci. V Aischylových Peršanech, kde rozmlouvá vdova po perském králi Dareiovi Attosa se starci a starci s poslem, se královna Attosa táže, kde vlastně leží Athény, které si hodlá podrobit její syn Xerxés, a jaká je jejich moc a bohatství. Starci královně vysvětlují, že Athény, které leží na západě, jsou bohaté na stř́ibro. Jejich význam je takový, že pokud Athény padnou, pak bude

i 1165-75 Theseus: Ó Adráste a ženy v Argu zrozené, zde vnuky vidíte - ti slavných otců svých sem nesou ostatky, jež vydobyl jsem vám; ty já a město darujeme jim i vám. Nám zachovejte vděčnou pamět' za ten čin a vězte, co mou zásluhou jste získali. A těmto synům chtěl jsem stejná slova říct: at' naše město ctí a děti dětem svým at' uvádějí v pamět', čeho dosáhly. (Eurípidés: Hippolytos a jiné tragédie, Praha 1986, str. 307)

1183-95 Athéna: A také, Thésee, slyš Athéninu řeč, co učinit bys měl, co získat činem tím. Těm synkům nedovol nést kosti do Argu jen bez závazku, nesmíš pustit je jen tak: dřív za své útrapy i obce athénské chtěj na nich přísahu a tou at' Adrástos se zaváže (je vladař s plnou mocí) dát slib tento za celou svou zemi argejskou; ta príísaha at' zní, že nikdy Argejci vás nenapadnou válkou, vojskem veškerým a vpádu jiných vojsk že budou odpor klást; a napadnou-li vás i přes tuto přísahu, at' za to zhyne bídně země argejská! ( Eurípidés: Hippolytos a jiné tragédie, Praha 1986, str. 308)

1232-34 Náčelnice sboru: Pojd'me, Adráste, a složme přísahu jemu a též městu. Úcty hodni jsou, co už pro nás snesli námah, strastí, běd. (Eurípidés: Hippolytos a jiné tragédie, Praha 1986, str. 310) 
dobyto celé Řecko. ${ }^{i}$ Občanské vojsko Athéňanů, přestože nemá vrchního velitele, nahání hrůzu nepřátelům, nebot' dokázalo rozprášit i velkolepou Dareiovu armádu (226-289). Když se na scénu dostaví posel s čerstvými a pro Peršany katastrofálními zprávami o výsledku bitvy mezi Řeky a Xerxovým vojskem u Salamíny, zazní v dialogu posla s jedním ze starců následující bolestné výkřiky (284-289):

Posel: Je hrozno slyšet pouhé to jméno: Salamis! A srdce zasténá, když řekneš: Athény!

Čtvrtý stařec: Athény! V nich je všecka bída jejich nepřátel. Přri slově tom myslím hned na perské ženy, kterým jste vzaly děti a muže! ${ }^{\mathrm{ii}}$

Athény jsou silou, o níž se rozbíjejí nepřátelská vojska. Porážka má pro Peršany zničující důsledky: Persie je zničena jako velmoc, nikdo nebude ctít perské zákony, nikdo nebude Peršanům odvádět daně a prokazovat jim úctu tím, že před nimi padne na zem (584-9). Porážka Peršanů znamená také svobodu pro jejich poddané (590-6). Otázka svobody byla ve spojitosti s vojenskou mocí velmi významnou a patřila mezi základní prvky athénské ideologie. Aischylos v Peršanech ukazuje, že svoboda podmiňuje vojenskou sílu (239-42), což je teze později zastávaná Hérodotem,

\footnotetext{
${ }^{\text {i }}$ Stejný názor zastával i Hérodotos (VII.139). Dle Hérodota se Athéňané stali zachránci celého Řecka. Přestože tato slova, jak říká Hérodotos, budou mnohým znít nelibě, je to pravda. Hérodotos opírá svůj názor o hypotetickou strategickou úvahu, v níž se snaží ukázat, že postoje Athén zásadně ovlivňuji situaci celého Řecka a rozhodly řecko-perské války. Kdyby se Athéňané nepostavili Peršanům na moři, neučinil by tak nikdo. Pokud by se bojovalo pouze na pevnině, pak se dá předpokládat, že spojenci Spart’anů by ze strachu desertovali a Spart'ané sami by tak obrovské přesile nemohli vzdorovat. Výsledkem by bylo podrobení celého Řecka perským králem. Tento názor byl za Periklea využíván Athéňany $\mathrm{k}$ obhajobě účelového čerpání společných prostředků z pokladnice délského spolku. Jestliže jsou Athény garantem bezpečnosti a svobody Řecka, mají právo v zájmu všech využívat finanční prostředky na budování armády a také staveb, které Peršané v průběhu bojů zničili.

ii Aischylos, Peršané (přel. Vladimír Šrámek), Praha 1994, str. 23.
} 


\section{AIOHIP II. 3}

Thúkydidem a Xenofóntem. Hérodotos se domníval, že vzrůst athénské moci a vojenské síly souvisel se svržením tyrannidy a se svobodou utvářet svůj život (V. 78). Xenofón $\mathrm{v}$ Anabasi vidí jako prríčinu vítězství v bitvě u Salamíny lásku řeckých obcí ke svobodě. ${ }^{i}$ Periklés v Pohřební řečii prohlašuje, že Athéňané rovněž převyšují své protivníky ve vojenském výcviku, což souvisí s jejich životním stylem a výchovou, pro niž je charakteristický svobodný způsob života a nikoli tuhá disciplína.

Pohled na Athény jako na stát s vůdčí úlohou je i v podloží Aischylových Eumenid, v nichž Orestés, který je poskvrněn matkovraždou, odchází na pokyn Apollóna do Athén, kde Athéna zřídí zvláštní soudní dvưr, který má Orestea osvobodit nebo vydat Líticím. Pro spravedlnost se tedy jde do Athén $\mathrm{k}$ athénskému soudu a krizové situace se řeší v Athénách.

Jak již bylo řečeno, tragédie mají mnoho politických aspektů, které nelze na tak krátkém prostoru zmínit, natož rozebírat. Zvolil jsem proto jeden z významných a zrètelně vystupujících aspektů svátků Velkých Dionýsií a tragédií, jimž je sebeprezentace a oslava Athén. Tento politický rozměr, jak jsem ukázal, je patrný jak v ceremoniálech, které hrám předcházely, tak $v$ hrách samotných. Není príliš nadnesené tvrdit, že tento politický akcent přehlušuje i demokratické hodnoty a ideály.

${ }^{\text {i } I I I . ~ 2 . ~} 13$.

ii Thúkydidés II. 39. 


\section{Literatura:}

Carter, D. M., 2007, The Politics of Greek Tragedy, Bristol.

Connor, W. R., 1989, City Dionysia and Athenian Democracy, Classica et Medievalia 40, s. 7-32.

Csapo, E., Slater W., 1994, The Context of Ancient Drama, Ann Arbor.

Goldhill, S., 1987, The Great Dionysia and Civic Ideology, Journal of Hellenic Studies 107, str. 58-76.

Godhill, S., 1992, The Great Dionysia and Civic Ideology, in: J. J. Winkler, F. I. Zeitlin, Nothing to Do with Dionysus? Princeton., s. 97-129.

Goldhill, S., 2000, Greek Drama and Political Theory, in: Rowe, Ch., Schofield, M. , The Cambridge History of Greek and Roman Political Thought. Cambridge, s. 60 - 88.

Loraux, N., 1981, L'Invention d'Athènes: Histoire de l'oraison funèbre dans la cité classique, Paris.

Loraux, N., Nagy, G., Slatkin, L ., 2001, Antiquities: Postwar French Thought, New York.

Osborne R., 1993, Competitive festivals and the polis: a context for dramatic festivals at Athens, in: A. H. Sommerstein a kol., Tragedy, Comedy and the Polis, Bari, s. 21-38.

Pickard-Cambridge, A. W. , 1969, The Attic Theater, New York.

Rhodes, P.J., 2003, Nothing to Do with Democracy, Journal of Hellenic Studies 123, s.104-119.

Wilson, P., 2003, The Athenian Institution of the Khoregia, Cambridge. 